\title{
Performance Improvement of Diagonal Type MHD Generator by Modification of PTO Electrode Configuration
}

\author{
Toru Takahashi Student Member (University of Tsukuba, takahashi@ fmm.kz.tsukuba.ac.jp) \\ Takayasu Fujino Member (University of Tsukuba) \\ Motoo Ishikawa Member (University of Tsukuba)
}

Keywords: diagonal type MHD generator, power takeoff, magnetohydrodynamic analysis

Time dependent three-dimensional numerical analysis is carried out in order to clarify causes of voltage loss occurring near power takeoff (PTO) regions and to suggest how to reduce the voltage loss for the scramjet engine driven MHD generator which was developed under the hypersonic vehicle electric power system program in USA. At the program, it is assumed that the MHD generator is located on the downstream of combustor in the channel of scramjet engine, and the electric power extracted by the MHD generator is utilized for an aerodynamic drag reduction, a thermal management for surface of vehicle, an aero braking, an aero steering, an inlet shock positioning control, and a MHD bypass assisted scramjet propulsion.

The HVEPS scramjet MHD power demonstration tests were successfully concluded. The result of power demonstration test, however, showed the considerable degradation of performance near the inlet and the outlet PTO regions. To understand the mechanism of this phenomenon is beneficial for the improvement of generator performance. The objective of the present analysis, therefore, is to examine the mechanism of performance degradation near the PTO regions, and also to propose the way for the improvement of performance degradation. The present numerical analysis modifies the number of the inlet and the outlet PTO electrodes to examine the optimum number of the PTO electrodes.

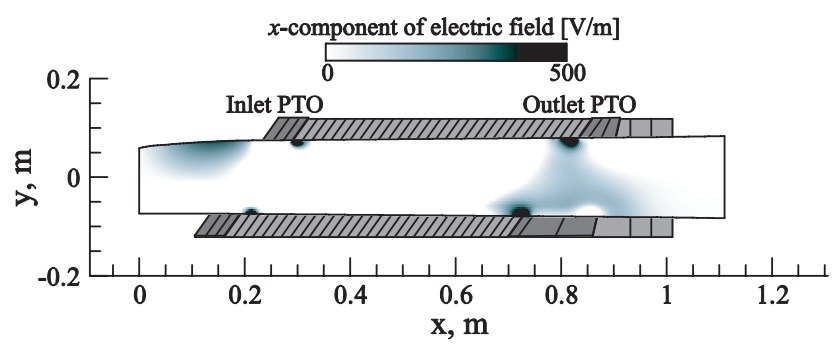

(a) Experimental electrode configuration

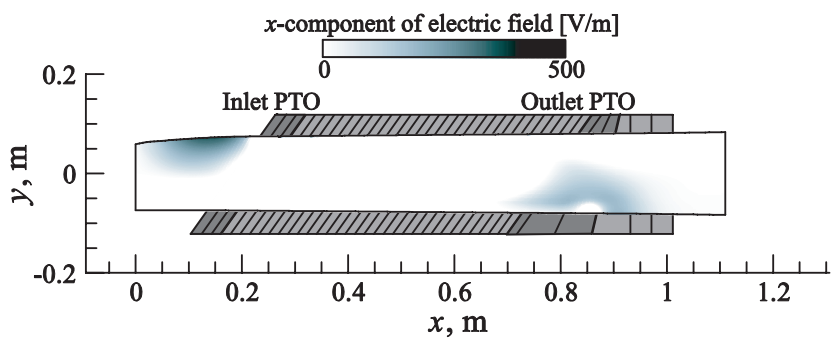

(b) Optimum electrode configuration

Fig. 1. Distribution of $x$-component of electric field near inlet PTO electrodes
Figure 1(a) shows the distribution of $x$-component of electric field when the number of the inlet and the outlet PTO electrodes are set to three and three, respectively, as same as the experimental electrode configuration, where the electric field is depicted in the range of $0 \mathrm{~V} / \mathrm{m}$ to $500 \mathrm{~V} / \mathrm{m}$. There are the local regions with positive electric field near the PTO electrodes. The phenomenon is due to both the relatively large loss of electric field by the current flow from electrodes and the weak electromotive force in the boundary layer near the PTO electrodes. The local regions with positive electric field deteriorate the generator performance. Figure 1(b) shows the distribution of $x$-component of electric field when the number of the inlet and the outlet PTO electrodes is, respectively, six and nine, which corresponds to the optimum number of the PTO electrodes. The electric field is also depicted in the range of $0 \mathrm{~V} / \mathrm{m}$ to $500 \mathrm{~V} / \mathrm{m}$. As can be seen from Fig. 1(b), the positive electric field is not observed near the PTO electrodes. Figure 2 shows the distribution of electrode potential. The voltage loss near the PTO electrodes occurs under the experimental electrode configuration. Under the optimum electrode configuration, on the other hand, the voltage loss disappears and the output voltage increases compared to the experimental electrode configuration. The electric power output under the optimum electrode configuration of PTO is improved by 22 percent, compared with the value in the experimental electrode configuration. These results, therefore, clearly show that the modification of the configuration of PTO electrodes leads to the improvement of generator performance.

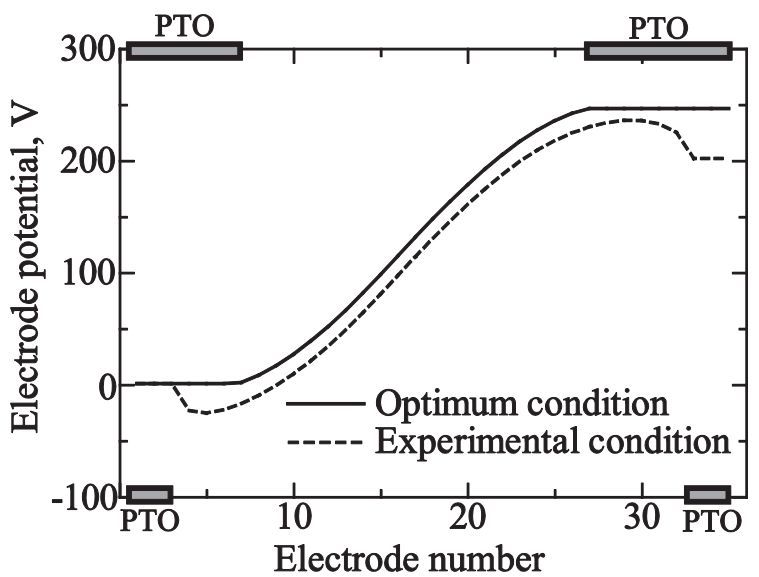

Fig. 2. Distribution of electrode potential under experimental and optimum electrode configuration 


\title{
PTO 電極構成の変更によるダイアゴナル形MHD 発電機の 性能改善に関する検討
}

\author{
学生員 高橋 徹* 正 員 藤野 貴康* \\ 正 員 石川 本雄*
}

\section{Performance Improvement of Diagonal Type MHD Generator by Modification of PTO Electrode Configuration}

Toru Takahashi*, Student Member, Takayasu Fujino*, Member, Motoo Ishikawa*, Member

Time dependent three-dimensional numerical analysis is carried out in order to clarify causes of voltage loss occurring near power takeoff regions and to suggest how to reduce the voltage loss for the scramjet engine driven MHD generator which was developed under the hypersonic vehicle electric power system program in USA. The numerical results under the experimental condition show that the local positive electric field is induced near the power takeoff electrodes. The phenomenon is due to the electric field loss by the high electric current through the weakly ionized plasma with low temperature and also by the low electromotive force near the power takeoff electrodes. When the configuration of power takeoff electrodes is modified, the current density near the power takeoff electrodes becomes small and the electromotive force becomes strong. The electric power output under the optimum electrode configuration of power takeoff is improved by 22 percent, compared with the value under the experimental condition.

キーワード : ダイアゴナル形 MHD 発電機, パワー・テークオフ, 電磁流体解析

Keywords: diagonal type MHD generator, power takeoff, magnetohydrodynamic analysis

\section{1. はじめに}

MHD 発電機は, 単純構造と高出力密度という特徴を有 することから，航空宇宙分野への応用が期待されており，こ れまでに超音速航空機内に MHD 発電機を搭載する研究が 各国において数多くなされてきた。数值解析的研究の一例 として，ロシアで提案された AJAX コンセプトに代表され る MHDエネルギーバイパスを適用したスクラムジェット エンジン内のプラズマ挙動を三次元数值解析により明らか にする研究が実施され(1)(2)，また国内においても MHD工 ネルギーバイパスの実用可能性に関する検討がなされてい る ${ }^{(3)}$ 。実験的研究としては, 近年, 次世代の超音速航空機 に搭載されるスクラムジェットエンジンの燃焼器下流側に MHD 発電機を設置し, 燃焼器から排出された燃焼ガスを 作動流体として用いることで，推進と同時に発電を行うス クラムジェットエンジン駆動 MHD 発電機の研究が米国の

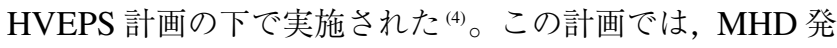

\footnotetext{
* 筑波大学大学院システム情報工学研究科

干 305-8573 つくば市天王台 1-1-1

Graduate School of Systems and Information Engineering, University of Tsukuba

1-1-1, Tennoudai, Tsukuba 305-8573
}

電により得られた電力は航空機周り，およびエンジン内の 流れの制御などに用いることが考えられており，その需要 を賄うためにはパルス的に $10 \mathrm{MW}$ 程度の電力が必要であ ると考えられている(5)(6)。実験では $6 \mathrm{~kW}$ 程度の発電出力が 得られ，その実用可能性が示されたが，電力取出電極（以 下, PTO 電極) 近傍で出力電圧に比べ比較的大きな電圧損 失が見られた。

著者らの研究グループでは，上述の実験で用いられたス クラムジェットエンジン駆動ダイアゴナル型 MHD 発電機 の実験装置を対象とし, MHD 発電機内で生じる現象の解 明を目的とした数值解析的研究を行ってきた (7)。解析結果 から, 発電機内の電磁流体挙動を明らかにし, 実験結果と のおおよその一致を得た ${ }^{(7)}$ 。また, 長岡技術科学大学の原 田らにおいても上述の発電機を対象とした数值解析が実施 され，実験で生じた主な損失は電極電圧降下現象によるも のであることが解明された ${ }^{(8)}$ 。しかし, 実験においてみら れた, PTO 電極近傍で生じた電圧損失の原因については未 だ解明されていない。

実験でみられたPTO 電極近傍の電圧損失の原因を解明 することが出来れば, 実験のみならず実用規模の MHD 発 電機の性能向上のための指針を与えることが出来ると考え られる。そこで本研究では, 実験条件下のスクラムジェッ 
トエンジン駆動 MHD 発電機を対象として三次元数值解析 を実施し, 得られた結果から PTO 電極近傍の現象を把握す るとともに電圧損失が発生する原因を解明する。またPTO 電極の構成を変更することで PTO 電極近傍で生じた電圧 損失を抑制し，発電損失を改善するための方法を提案する。

\section{2. 数值解析手法}

〈2・1〉解析領域 Fig. 1 に解析領域ならびに座標系を 示す。解析領域は，遷移ダクト部 $(0.237 \mathrm{~m})$, 発電チャネ ル部 $(0.744 \mathrm{~m})$ ，およびノズル $(0.136 \mathrm{~m})$ からなる。ここ で，発電チャネル部においては計 38 枚の銅製電極フレーム が絶縁壁に隔たれて配置されている。そのうち，発電機入 口から数えて $1 \sim 33$ 番電極は $x$ 方向に対して 60 度の傾き を有し，34３6 番電極は $x$ 方向に対して 60 度から 90 度 に遷移している。また，発電機入口から数えて $1 \sim 3$ 番電極 および 33〜35 番電極は実験と同様にPTO 電極とした。な お， $z$ 方向はチャネルの対称性を考慮し，半分の範囲を解 析領域とした。

〈2・2〉 基礎方程式および解析手法 流体力学的諸量 の基礎方程式には，以下に示す連続の式，MHD効果をソー ス項に含んだ運動量保存の式およびエネルギー保存の式, 気体の状態方程式を用いた。流体力学的諸量の基礎方程式 は Harten-Yee の風上型 TVD 法 ${ }^{(9)}$ を用いて解いた。

$$
\begin{aligned}
& \frac{\partial \rho}{\partial t}+\nabla \cdot(\rho \boldsymbol{u})=0 \\
& \frac{\partial}{\partial t}(\rho \boldsymbol{u})+\nabla \cdot(\rho \boldsymbol{u} \boldsymbol{u})=-\nabla p+\nabla \cdot \tau_{i j}+\boldsymbol{j} \times \boldsymbol{B} \cdots \\
& \frac{\partial E_{0}}{\partial t}+\nabla \cdot\left(\left\{E_{0}+p\right\} \boldsymbol{u}\right)=\nabla \cdot\left(\tau_{i j} \boldsymbol{u}+\kappa \nabla T\right)+\boldsymbol{j} \cdot \boldsymbol{E} \\
& \text {................ (3) } \\
& p=\rho R T \\
& E_{o}=\rho\left(e+\frac{\boldsymbol{u}^{2}}{2}\right)
\end{aligned}
$$

ここで， B は磁束密度ベクトル，e は内部エネルギー, $E_{0}$ は全エネルギー, $\boldsymbol{E}$ は電界強度ベクトル， $\boldsymbol{j}$ は電流密度べ クトル, $p$ は静圧， $R$ は気体定数， $t$ は時間， $T$ は静温， $\boldsymbol{u}$ は速度べクトル， $\kappa$ は熱伝導率， $\rho$ は質量密度， $\tau_{i j}$ は粘性 応力テンソルである。乱流モデルには, Prandtlの混合長モ

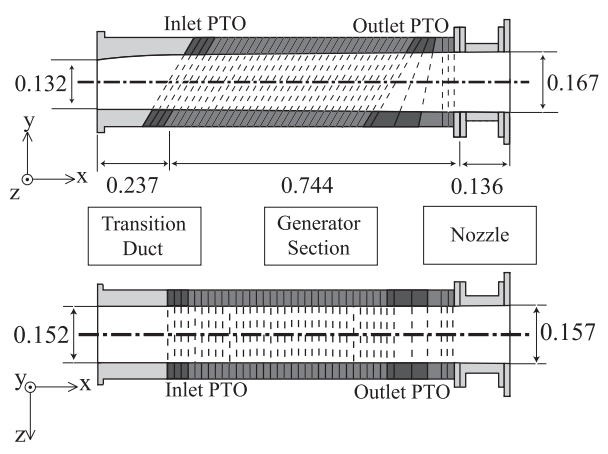

Fig. 1. Configuration of MHD generator and coordinate system.
デルに基づいて Cebeci と Smith が提案し, Stock と Haase が修正したモデル(10)を用いた。

電磁気学的諸量の基礎方程式には以下に示す MHD 近似 を施した Maxwell 方程式，および一般化されたオームの法 則を用いた。

$$
\begin{aligned}
& \nabla \times \boldsymbol{E}=\mathbf{0} \ldots \ldots \ldots \ldots \ldots \ldots \ldots \ldots \ldots \ldots \ldots \ldots \ldots \\
& \nabla \cdot \boldsymbol{j}=0 \ldots \ldots \ldots \ldots \\
& \boldsymbol{j}=\sigma(\boldsymbol{E}+\boldsymbol{u} \times \boldsymbol{B})-\frac{\beta}{|\boldsymbol{B}|}(\boldsymbol{j} \times \boldsymbol{B})
\end{aligned}
$$

ここで， $\beta$ はホールパラメータ， $\sigma$ は電気伝導度である。 Maxwell 方程式，および一般化されたオームの法則から導 出される以下の電位に関する二階の偏微分方程式は, 四面 体要素を用いた Galerkin 有限要素法 ${ }^{(11)} に よ り$ 解いた。

$$
\begin{aligned}
& \frac{\partial}{\partial x}\left[\frac { \sigma } { 1 + \beta ^ { 2 } } \left\{-\frac{\partial \phi}{\partial x}\left(1+\frac{\beta^{2}}{|\boldsymbol{B}|^{2}} B_{x}^{2}\right)-\frac{\partial \phi}{\partial y}\left(-\frac{\beta}{|\boldsymbol{B}|} B_{z}\right)\right.\right. \\
& \left.\left.-\frac{\partial \phi}{\partial z}\left(\frac{\beta^{2}}{|\boldsymbol{B}|^{2}} B_{z} B_{x}\right)+\frac{\beta}{|\boldsymbol{B}|}\left(u_{x} B_{z}^{2}-u_{z} B_{z} B_{x}\right)+u_{y} B_{z}\right\}\right] \\
& +\frac{\partial}{\partial y}\left[\frac { \sigma } { 1 + \beta ^ { 2 } } \left\{-\frac{\partial \phi}{\partial x}\left(-\frac{\beta}{|\boldsymbol{B}|} B_{z}\right)-\frac{\partial \phi}{\partial y}\right.\right. \\
& \left.\left.-\frac{\partial \phi}{\partial z}\left(-\frac{\beta}{|\boldsymbol{B}|} B_{x}\right)+\frac{\beta}{|\boldsymbol{B}|}\left(u_{y} B_{z}^{2}+u_{y} B_{x}^{2}\right)+u_{z} B_{x}-u_{x} B_{z}\right\}\right] \\
& +\frac{\partial}{\partial z}\left[\frac { \sigma } { 1 + \beta ^ { 2 } } \left\{-\frac{\partial \phi}{\partial x}\left(-\frac{\beta^{2}}{|\boldsymbol{B}|^{2}} B_{z} B_{x}\right)-\frac{\partial \phi}{\partial y}\left(-\frac{\beta}{|\boldsymbol{B}|} B_{x}\right)\right.\right. \\
& \left.\left.-\frac{\partial \phi}{\partial z}\left(1+\frac{\beta^{2}}{|\boldsymbol{B}|^{2}} B_{z}^{2}\right)+\frac{\beta}{|\boldsymbol{B}|}\left(-u_{x} B_{z} B_{x}+u_{z} B_{x}^{2}\right)-u_{y} B_{x}\right\}\right] \\
& =0
\end{aligned}
$$

ここで, $B_{x}, B_{z}$ は磁束密度の $x, z$ 方向成分, $u_{x}, u_{y}, u_{z}$ は速 度の $x, y, z$ 方向成分， $\phi$ は電位である。

〈2·3 解析条件 流体場の解析条件として, 流路入 口には Table 1 に示す HVEPS 計画の下で実施された実験 の運転条件に合うように与えた。なお，入口温度について は, Fig. 2 に示す米国の研究グループにより行われたスク ラムジェットエンジン燃焼器内の三次元数值解析の結果か ら得られた温度分布を与えた(5)。また，境界層内の温度お よび速度については $1 / 5$ 乗則により求めた。流路出口にお ける流体の境界条件は自由流出条件とした。流路内部の諸 量については入口から出口にかけて適切と考えられる勾配 を持つ分布を初期值として与えた。流体の壁面における境 界条件にはno-slip 条件を用い, 壁温は $1000 \mathrm{~K}$ 一定と仮定 した。また，電気伝導度については解析結果および実験結 果から得られた発電領域中央の電極電位勾配が一致するよ うに，熱化学平衡計算により求められた電気伝導度の值の 0.5 倍とした。電磁場の境界条件として, 絶縁壁および入 口，出口境界では次式を与えた。

$$
\boldsymbol{j} \cdot \boldsymbol{n}=0
$$

ここで， $\boldsymbol{n}$ は単位法線ベクトルである。また，電極上の境 界条件として，入口側および出口側 PTO 電極上ではそれぞ 
Table 1. Operating condition for experiment of diagonal type MHD generator ${ }^{(4)}$.

\begin{tabular}{|c|c|}
\hline Combustion efficiency (\%) & 89 \\
\hline Pre-heater $\mathrm{H}_{2}$ flow $(\mathrm{kg} / \mathrm{s})$ & 0.031 \\
\hline Air flow $(\mathrm{kg} / \mathrm{s})$ & 0.595 \\
\hline $\mathrm{O}_{2}$ enrichment flow $(\mathrm{kg} / \mathrm{s})$ & 0.659 \\
\hline Seed $(\mathrm{NaK})$ flow $(\mathrm{kg} / \mathrm{s})$ & 0.038 \\
\hline Scramjet combustor fuel(ethylene) flow $(\mathrm{kg} / \mathrm{s})$ & 0.160 \\
\hline Total flow rate $(\mathrm{kg} / \mathrm{s})$ & 1.483 \\
\hline Inlet static pressure (atm) & 0.283 \\
\hline Inlet static temperature $(\mathrm{K})$ & 2480 \\
\hline Channel length $(\mathrm{m})$ & 1.1176 \\
\hline Inlet height $(\mathrm{m})$ & 0.1329 \\
\hline Inlet width $(\mathrm{m})$ & 0.1524 \\
\hline Outlet height $(\mathrm{m})$ & 0.1670 \\
\hline Outlet width $(\mathrm{m})$ & 0.1569 \\
\hline Diagonalization angle $\left({ }^{\circ}\right)$ & 60 \\
\hline
\end{tabular}

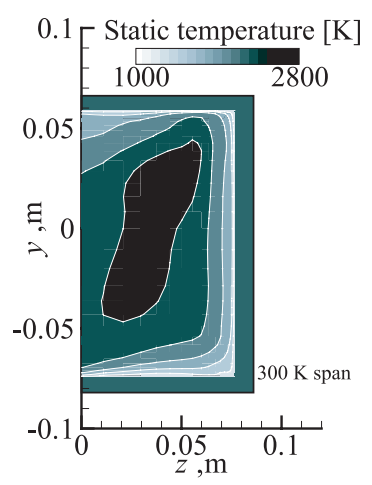

Fig. 2. Distribution of inlet static temperature on $y-z$ plane $(x=0 \mathrm{~m})$.

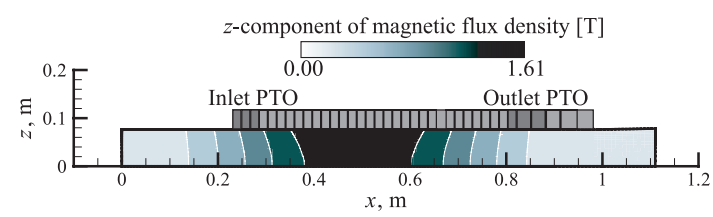

(a) $z$-component of magnetic flux density $\left(B_{z}\right.$, measured)

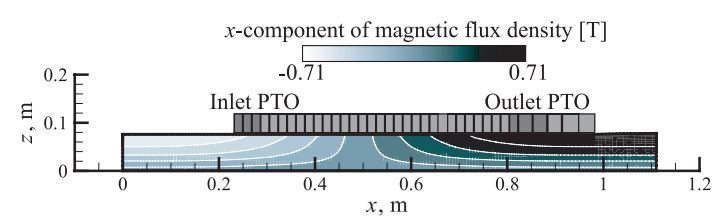

(b) $x$-component of magnetic flux density $\left(B_{x}\right.$, calculated)

Fig. 3. Distributions of magnetic flux density $(y=0 \mathrm{~m})$.

れ等電位境界条件を与え，他の電極上には実験で測定され た負荷電流值（約 $58 \mathrm{~A}$ ）を満足するような電位を固定境界 条件として与えた。印加磁束密度については，実験と同様 の分布を与えた。ただし, 磁束密度は $x$ 方向, および $z$ 方 向成分のみをもつと仮定した。Fig. 3 に $y=0 \mathrm{~m}$ における 磁束密度の $x-z$ 平面分布を示す。以下では, 全ての諸量の 分布が定常状態に達した後の結果を示す。

\section{3. 解析結果および考察}

$\langle\mathbf{3} \cdot \mathbf{1}\rangle \quad$ 実験条件における発電性能

Fig. 4 に, $z=0$

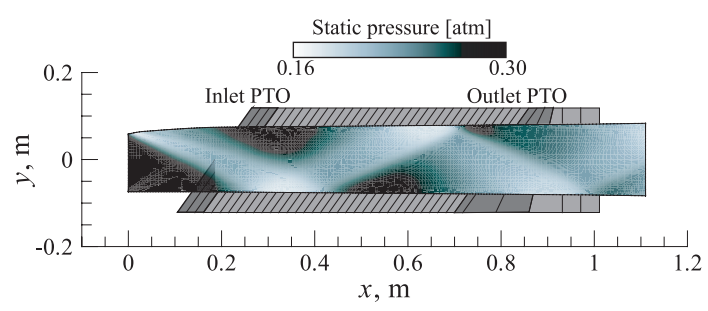

Fig. 4. Distribution of static pressure on $x-y$ plane $(z=0 \mathrm{~m})$.

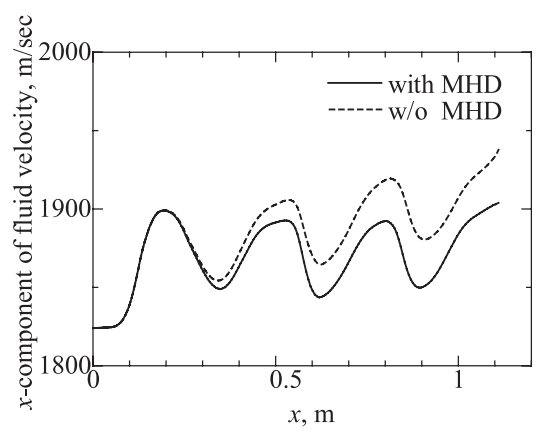

Fig. 5. Distributions of $x$-component of fluid velocity with and without MHD interaction along center line of channel.

$\mathrm{m}$ における静圧の $x-y$ 平面分布を示す。数值解析結果をみ ると発電機流路入口上部から圧縮波および膨張波が発生し, その影響が流路全域の流れ場に及んでいることがわかる。 ただし，実験において流体の可視化は行われていないため， 今後の検討が必要である。Fig. 5 に発電条件下, 非発電条 件下それぞれにおける発電機中心軸上の流速の $x$ 方向成分 分布を示す。流路出口において, 発電条件下で得られた速 度は非発電条件下の流速に比べ減少していることがわかる。 これは，流体場と電磁場の相互作用によって生じた $x$ の負 方向にかかるローレンツカによるものである。この流体場 と電磁場の相互作用の強さを, (11) 式で定義される MHD 相互作用係数 $S_{p}$ により評価した。

$$
S_{p}=\frac{\int_{V_{\text {all }}} j_{y} B_{z} d V}{\int_{S_{\text {in }}}\left(p+\rho u_{x}^{2}\right) d S}
$$

ここで, $j_{y}$ は電流密度の $y$ 方向成分, $V_{\text {all }}$ は発電機流路の 全容量, $S_{i n}$ は発電機流路入口の断面積である。(11) 式から MHD 相互作用係数を評価すると約 $2.5 \times 10^{-2}$ となり, 著 者らの研究グループでこれまで解析されてきた地上パルス 大電力 MHD 発電機（例えば, 文献 (12)）に対して, 比較 的低い值をとった。すなわち, MHD 発電機における流体 場と電磁場の相互作用は弱く, その発電性能は極めて低い ことがこのことからも推測できる。Fig. 6 に, 解析結果よ り得られた電極電位の分布を示す。図より, 入口側および 出口側 PTO 電極近傍において電位勾配が流れ方向に対し て負となる電圧損失が生じていることがわかる。この電圧 損失の大きさは, 出力電圧に対して約 $30 \%$ の割合を占めて 


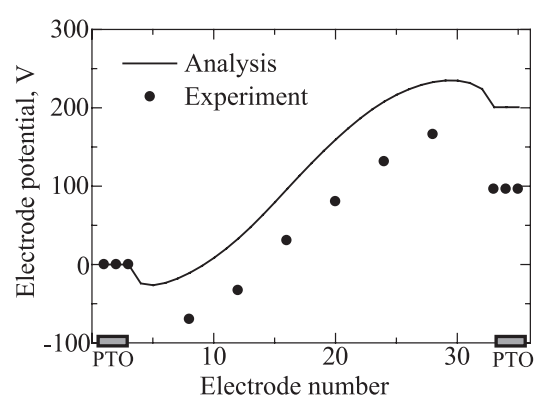

Fig. 6. Distribution of electrode potential obtained by three dimensional numerical analysis and power demonstration experiment.

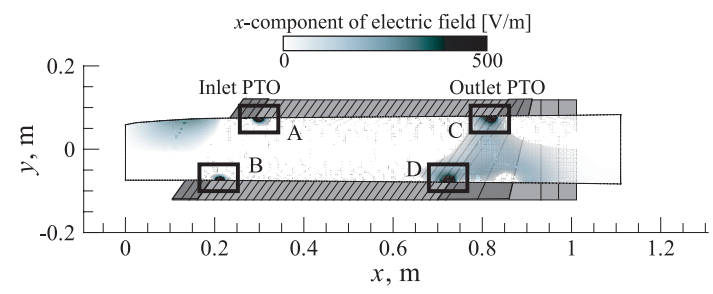

Fig. 7. Distributions of electric field in $x$-direction $(z=0 \mathrm{~m})$.

おり，発電機の損失に大きく影響を与えていることがわか る。しかし実験で計測された電圧損失と比較すると，大き な差異がみられる。この原因として PTO 電極上の電流密 度の大きさが他の電極に比べて約 2 倍程度大きいため, 解 析では考慮していない現象が生じていると考元られるそ の一つにPTO 電極における電流集中現象が挙げられるが, 本解析で用いた解析格子では電流集中現象を捉えるほどの 解像度を有していない。従って, 電流集中現象を捉えるこ とを目的とした数值解析は今後の課題である。なお，数值 解析で得られた発電出力は $11.6 \mathrm{~kW}$ であった。

Fig. 7 に, 発電機流路内部の $z=0 \mathrm{~m}$ に扔ける電界強度 の $x$ 方向成分の分布を示す。ここで説明の便宜上，実質的 に発電を行っていない領域を表すために，電界強度を 0 $+500 \mathrm{~V} / \mathrm{m}$ の範囲に限定して図示した。なお， $x$ 方向電界が 正の值を示すとき，その領域は非発電領域に相当する。同 図から，入口側および出口側 PTO 電極近傍において，電 界強度の $x$ 方向成分が正となる領域が局所的に発生してい ることがわかる。なお，入口側および出口側を比較すると， 電界強度が正の領域に違いがみられるが，これは最大磁場 の位置が入口側 PTO 寄りであること，および入口側 PTO から電流が流出する面積と出口側 PTO に電流が流入する 面積が異なることによる。局所的な $x$ 方向の正電界が発生 している領域を図中に示すように $\mathrm{A} \sim \mathrm{D}$ としたとき，各領 域中で $x$ 方向の正電界が最大值をとる点について，一般化 されたオームの法則を電界強度の $x$ 方向成分について整理 することにより導出される次式の各項を評価する。

$$
E_{x}=\frac{j_{x}}{\sigma}-u_{y} B_{z}+\frac{1}{\sigma} \frac{\beta}{|\boldsymbol{B}|} j_{y} B_{z}
$$

ここで， $E_{x}$ は電界強度の $x$ 方向成分である。なお，左辺は
Table 2. Values of each term in Eq.(12) at points with maximum electric field in the regions of A - D.

\begin{tabular}{|c|c|c|c|c|}
\hline Regions & A & B & C & D \\
\hline Electric field, V/m & 1830 & 1810 & 1780 & 1490 \\
\hline Electric field loss, V/m & 7010 & 2130 & 1850 & 3410 \\
\hline Faraday electromotive force, $\mathrm{V} / \mathrm{m}$ & -1.24 & 0.74 & -0.39 & 0.30 \\
\hline Hall electromotive force, $\mathrm{V} / \mathrm{m}$ & -5180 & -320.0 & -77.30 & -1920 \\
\hline
\end{tabular}

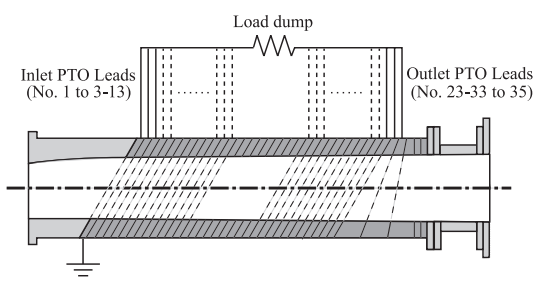

Fig. 8. Configuration of PTO electrodes.

電界強度の $x$ 方向成分，右辺第一項はプラズマ中を流れる 電流による電界損失，右辺第二項，第三項はそれぞれ $x$ 方 向に作用するファラデー起電力およびホール起電力を表す。 Table 2 に, 領域 $\mathrm{A} \sim \mathrm{D}$ に打いて (12) 式の各項を求めた結 果を示す。Table 2 から, 局所的な $x$ 方向の正電界が生じ た各領域に拈いて，ファラデー起電力が電界強度の $x$ 方向 成分に及ぼす影響は小さいことがわかる。また, Fig. 2 中 の壁面近傍に扔ける温度の低い気体中を電流が流れること により大きな電界損失が生じ，その領域におけるホール起 電力が低いために, $x$ 方向の正電界が生じることがわかる。 PTO 電極近傍の電界損失が比較的大きくなる原因は, 全負 荷電流が PTO 電極に流入あるいは流出することが強制さ れることによる。

$\langle\mathbf{3} \cdot 2\rangle \quad P T O$ 電極構成の变更に伴う電圧損失の変化 前 節で述べた局所的な $x$ 方向の正電界を抑制する方法として, 電極数, およびその位置は実験条件と同様とし, PTO を構 成する電極数のみを増やすことを検討した。これは, PTO 電極から流路内のプラズマに流出，あるいはプラズマから PTO 電極に流入する電流をPTO 電極数を増やすことで分 散させて電極近傍の電流密度を減少し, 電界損失を低減す ること，および PTO を構成する電極のうち， $x$ 方向の流路 中央部 $(x=0.5 \mathrm{~m})$ に近い側の電極の位置を磁束密度が強 い領域に配置することで，ホール起電力の増加を狙ったも のである。本解析では，Fig. 8 に示すように，入口側拉よ び出口側 PTO 電極数を $3 \sim 13$ の範囲で変化させ, 電圧損 失が抑制される電極数を求めた。なお，本論文では紙面の 都合上, 出口側電極数を実験条件と同様 3 に固定し, 入口 側 PTO 電極数のみを変更したときの結果を示す。

Fig. 9 に，入口側 PTO 電極数を $3 \sim 6$ の範囲で変化させ たときの Fig. 7 中の A 領域に扔ける電界強度の $x$ 方向成分 を示す。ここでも Fig. 7 と同様，電界強度を $0 \sim+500 \mathrm{~V} / \mathrm{m}$ の範囲に限定して図示している。同図をみると，局所的な $x$ 方向の正電界は PTO を構成する電極のうち, $x$ 方向の流 路中央部 $(x=0.5 \mathrm{~m})$ に近い側の電極近傍で生じている。 また，入口 PTO 電極数を増加するにつれて局所的な $x$ 方 


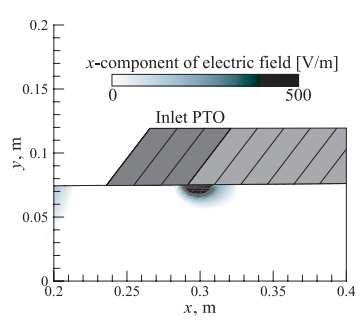

(a) Number of inlet PTO electrodes: 3

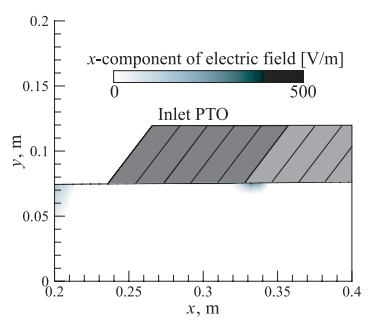

(c) Number of inlet PTO electrodes: 5

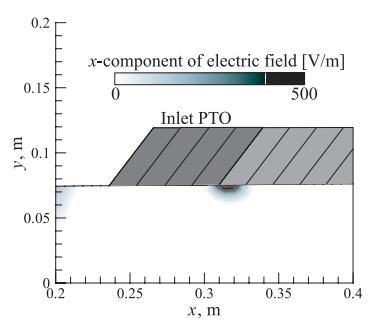

(b) Number of inlet PTO electrodes: 4

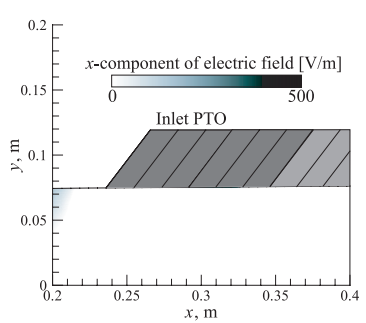

(d) Number of inlet PTO electrodes: 6
Fig. 9. Distribution of electric field in $x$-direction near inlet PTO electrodes on $x-y$ plane $(z=0 \mathrm{~m})$.

Table 3. Values of each term in Eq.(12) at the point with maximum electric field in region of A in the case of 3-6 electrodes.

\begin{tabular}{|c|c|c|c|c|}
\hline Number of inlet PTO electrodes & 3 & 4 & 5 & 6 \\
\hline Electric field, V/m & 1830 & 1080 & 514 & 44 \\
\hline Electric field loss, V/m & 7010 & 6360 & 5990 & 5740 \\
\hline Faraday electromotive force, V/m & -1.24 & -1.35 & -1.45 & -1.55 \\
\hline Hall electromotive force, V/m & -5180 & -5280 & -5470 & -5690 \\
\hline
\end{tabular}

向の正電界は抑制され，入口側 PTO 電極数を 6 としたと き， $x$ 方向の正電界は発生しなくなることがわかる。この とき, Fig. 7 に示した $\mathrm{A}$ 領域中で $x$ 方向の正電界が最大值 をとる位置について入口側 PTO 電極数を 3 6 の間で変化 させたときの (12) 式の各項を求めた結果を Table 3 に示 す。Table 3 から，入口側 PTO 電極数を増加するにつれて， 電界損失は減少することがわかる。一方でホール起電力の 絶対值は増加する。その結果, 入口側 PTO 電極数を 6 と した条件においては $x$ 方向の正電界は殆ど生じていないこ とがわかる。

Fig. 10 に，入口側の各 PTO 電極から流出する電流值を 示す。この図から, PTO 電極数の増加に伴い, 各電流から 流出する電流值は減少しており, 特にPTOを構成する電極 のうち, 最後の電極から流出する電流が低下することがわ かる。この電流の低下に伴い, PTO を構成する最後の電極 近傍における電流密度の $x$ 方向成分は低下し, 結果として 電界損失が減少したと考えられる。

PTO 電極数を増やすことによりホール起電力の絶対值が 増加する理由は, PTO 電極を構成する電極のうち, 最後の 電極の位置が $x$ 方向の流路中央部 $(x=0.5 \mathrm{~m})$ に近づくに つれ，磁束密度の $z$ 方向成分が増加することに起因すると 考えられる。Table 4 に, 入口側 PTO 電極数を 3〜6とした ときの, Fig. 7 に示した A 領域中で $x$ 方向の正電界が最大

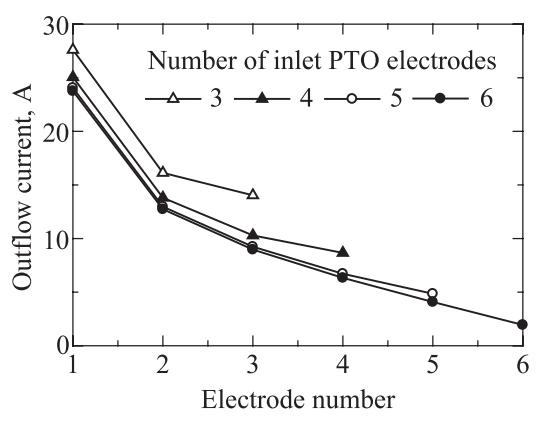

Fig. 10. Relation between outflow of current from inlet PTO electrodes and number of PTO electrodes.

Table 4. Hall electromotive force at the point with maximum electric field in region of A in the case of 3-6 electrodes.

\begin{tabular}{|c|c|c|c|c|}
\hline Number of inlet PTO electrodes & 3 & 4 & 5 & 6 \\
\hline Currentdensityiny-direction, $\mathrm{A} / \mathrm{m}^{2}$ & -1310 & -1220 & -1180 & -1150 \\
\hline Magneticfluxdensityinz-direction, $\mathrm{T}$ & 0.934 & 1.014 & 1.089 & 1.160 \\
\hline Hall parameter & 0.409 & 0.445 & 0.479 & 0.510 \\
\hline Hall electromotive force, $\mathrm{V} / \mathrm{m}$ & -5200 & -5280 & -5470 & -5690 \\
\hline
\end{tabular}

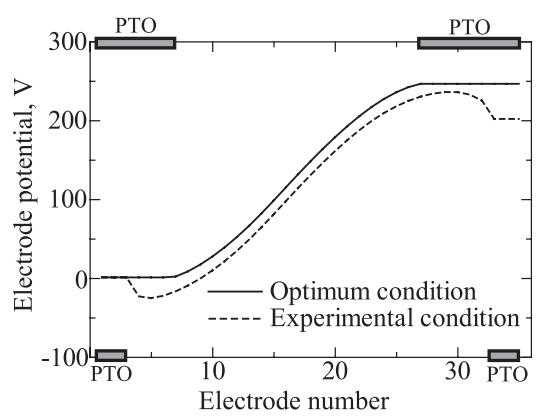

Fig. 11. Distribution of electrode potential under experimental and optimum electrode configuration.

值をとる位置における電流密度の $y$ 方向成分, 磁束密度の $z$ 方向成分, ホールパラメータ, およびホール起電力の值を 示す。この表から, 入口側 PTO 電極数を増やすことにより 電流密度の $y$ 方向成分の絶対值は低下しているものの, 磁 束密度の $z$ 方向成分とともにホールパラメータが増加して いることが確認できる。

Fig. 11 に PTO 電極数を変更した場合の電極電位分布を 示す。なお, 出口側 PTO 電極数は入口側と同様に求め, 電 圧損失が抑制されるときの電極数である 9 とした。同図か ら, 磁束密度が低く発電のために起電力が得られない領域 において, PTO 電極数を増加することで電圧損失を抑制し, 発電性能を向上できることが示唆された。このとき, 発電 出力約 $14.2 \mathrm{~kW}$ が得られ, 実験条件の PTO 電極数としたと きの解析結果に対して約 $22 \%$ 改善された。なお, 本解析で は実験機の電極の形状および全電極数を既存の装置と一致 させて行うことを条件としたが, 発電機の全電極数およびそ の配置領域に関しても最適化が必要であるため今後の研究 課題とする。また, このときの発電機流路内部の $z=0 \mathrm{~m}$ に おける電界強度の $x$ 方向成分分布を Fig. 12 に示す。Fig. 7 との比較より, PTO 電極近傍において局所的な $x$ 方向の正 


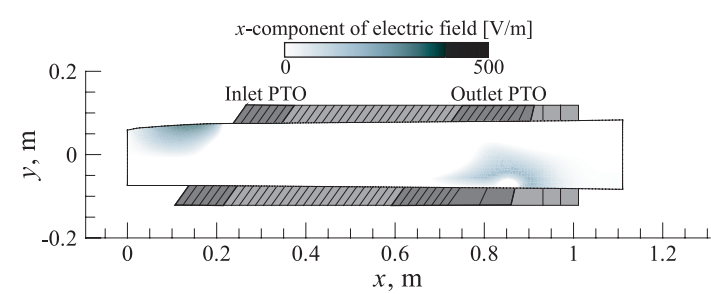

Fig. 12. Distribution of electric field in $x$-direction under optimum electrode configuration $(z=0 \mathrm{~m})$.

電界が発生していないことがわかる。

\section{4. まとめ}

本論文では，米国で開発されたスクラムジェットエンジ ン駆動ダイアゴナル形MHD 発電機実験装置を対象として 三次元数值解析を実施し，実験および解析結果でみられた PTO 領域近傍における電圧損失の原因を解明するとともに, 電圧損失を改善するための一つの手法を提案した。得られ た主な結果を以下に記述する。

（1）実験条件下の PTO 電極近傍において, 温度の低い 気体中を電流が流れることにより大きな電界損失が生じ, その領域では起電力が低いために，局所的な $+x$ 方向の電 界が発生していることが明らかとなった。

（2） PTO 電極近傍で電圧損失が発生しないよう PTO 電 極数を変更したとき, 発電出力は実験条件に対して約 $22 \%$ 改 善された。実験および実用規模の発電機を設計・運用する 際には，PTO 電極の構成を最適化することが有用であるこ とが示された。

(平成 21 年 6 月 11 日受付, 平成 22 年 4 月 7 日再受付)

\section{文献}

(1) E.P. Gurijanov and Ph. T. Hirsha: "AJAX: New directions in hypersonic technology", 7th Aerospace Planes and Hypersonics Technology Conference, AIAA Paper 96-4609, Norfolk, England (1996-4)

(2) D.V. Gaitonde: "Magnetohydrodynamic Energy-Bypass Procedure in a Three-Dimensional Scramjet", J. Propulsion \& Power, Vol.22, No.3, pp.498-510 (2006)

（3）神永 晋・富岡定毅・山岬裕之：「MHD エネルギーバイパスを用い たスクラムジェットエンジンの性能」, 航空宇宙学論, Vol.53, No.623, pp.554-561 (2005)

(4) J.T. Lineberry, L. Begg, J.H. Castro, R.J. Litchford, and J.M. Donohue: "HVEPS Scramjet-Driven MHD Power Demonstration Test Results", 38th AIAA Plasmadynamics and Lasers Conference In conjunction with the 16th International Conference on MHD Energy Conversion, AIAA-2007-3881, Miami, USA (2007-6)

(5) J.T. Lineberry, L. Begg, J.H. Castro, and R.J. Litchford: "Scramjet Driven MHD Power Demonstration - HVEPS Program", 37th AIAA Plasmadynamics and Lasers Conference, AIAA paper 2006-3080, San Francisco, USA (2006-6)

(6) J.T. Lineberry, L. Begg, J.H. Castro, and R.J. Litchford: "Scramjet Driven MHD Power Demonstration - HVEPS Program Overview”, 14th AIAA/AHI International Space Planes and Hypersonic Systems and Technologies

Conference, AIAA-2006-8010, Canberra, Australia (2006-11)

(7) D. Gotoh, T. Takahashi, T. Fujino, M. Ishikawa, and J.T. Lineberry: "Computational Analysis of HVEPS Scramjet MHD Power Generation", 38th AIAA Plasmadynamics and Lasers Conference In conjunction with the 16th International Conference on MHD Energy Conversion, AIAA-2007-4015, Miami, USA (2007-6)

(8) T. Hardianto, N. Sakamoto, and N. Harada: "Performance Study of a Diagonal Conducting Wall MHD Power Generation”, 38th AIAA Plasmadynamics and Lasers Conference In conjunction with the 16th International Conference on MHD Energy Conversion, AIAA-2007-4016, Miami, USA (2007-6)

(9) H.C. Yee: "Upwind and Symmetric Shock-Capturing Schemes", NASA TM-89464 (1987-5)

(10) H.W. Stock and W. Haase: "The Determination of Turbulent Length Scales in Algebraic Turbulence Models for Attached and Slightly Separated Flows Using Navier-Stokes Methods", 19th AIAA Fluid Dynamics, Plasma Dynamics \& Lasers Conference, AIAA paper 87-1302, Honolulu, USA (19876)

（11）中田高義 ·高橋則雄 : 電気工学の有限要素法, 森北出版 (1986)

(12) M. Yuhara, T. Fujino, M. Ishikawa, and J.T. Lineberry: "Three-Dimensional Analysis of a Large-Scale Pulsed MHD Generator", 15th International Conference on MHD Energy Conversion, Vol.1, pp.285-293 (2005)

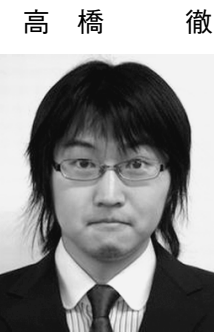

（学生員） 1984 年 9 月 23 日生。 2007 年 3 月筑 波大学第三学群工学システム学類卒業。2009 年 3 月筑波大学大学院システム情報工学研究科構造 エネルギー工学専攻博士前期課程修了。同年 4 月 同大学大学院システム情報工学研究科構造エネル ギー工学専攻博士後期課程入学。主として MHD 発電に関する研究に従事。

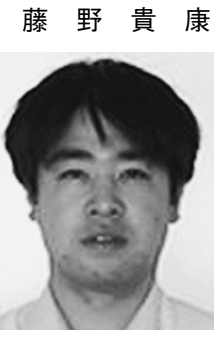

（正員） 1974 年 7 月 16 日生。1997 年 3 月東京 理科大学理学部応用物理学科卒業。1999 年 3 月 東京工業大学大学院総合理工学研究科創造エネル ギー工学専攻修士課程修了。2002 年 3 月同大学 院博士後期課程修了。2002 年 4 月～2004 年 7 月 日本学術振興会特別研究員 PD。2004 年 7 月 筑波大学大学院システム情報工学研究科構造エネ ルギー工学専攻講師。この間，主としてプラズマ MHD 発電，MHD 技術の航空宇宙応用の研究に従事。博士 (工学)。

石川本 雄

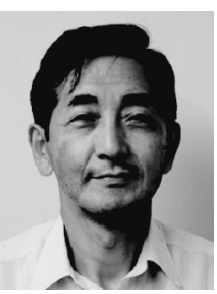
発電, D-3He 核融合炬における直接エネルギー変換, 超長距離大電力 直流送電などの研究に従事。工学博士。 